\title{
Moderate Islamic Value as a Source of Students' National Identity to Support Students' Sociocultural Literacy
}

\author{
Agung D.B. El Rizaq ${ }^{1, *}$ Siti Azizah ${ }^{2,}$ Shinta Oktafiana ${ }^{3}$ \\ 1,2,3 Tadris IPS, Fakultas Tarbiyah, Institut Agama Islam Negeri Madura, Pamekasan, Indonesia \\ *Corresponding author. Email: elrizaq@iainmadura.ac.id
}

\begin{abstract}
This research focuses on implementing moderate Islamic values in school programs related to national identity. This research is beneficial for strengthening students' character in accepting diversity in Indonesia, maintaining national unity, preserving Indonesian culture, and strengthening religious moderation and inter-religious harmony. This survey study is based on the three-stage probability proportion of 50 students as subjects from nine cities in East Java. Our findings show that moderate Islamic values have been integrated into several school programs such as intra-curricular, extracurricular, school culture, and community participation to strengthen national identity. Then, it is essential to design a program for strengthening student identity as a reference for public schools to facilitate the improvement of sociocultural literacy for students.
\end{abstract}

Keywords: Indonesian, Moderate Islamic value, Students' National Identity.

\section{INTRODUCTION}

National identity is important for nations to maintain the rapid flow of globalization and technological development, which may drive individuals to abandon their culture and replace it with the global culture [1]. Entering the era of globalization, the level of racial, ethnic, and cultural diversity in nation-states in the world is getting higher. Still, the concept of national identity must be maintained [2]. National identity is a historical context that is "unique" from each country [3] which comes from religious identity [4], ideology and language [5], history [6], and self-esteem [7].

National identity has several defines based on its function and condition. It emerged as a form of modern nationalism [8]. The national identity is built on the past collective memories [9], [10]. In the micro condition, national identity is the recognition of being part of a group with similar emotions [11] and the behavior of loving domestic products [12].

National identities have different characteristics in every country. For example, in the U.K., the measure of national identity is self-esteem [13]. When people are treated with respect and tolerance, they feel like a part of England. Unlike in Scotland, place of residence is the key to being "Scotland", and ancestry (ethnoreligious background) is also a marker of national identity [14]. In the Netherlands, national identity is related to the behavior of limiting the consumption of foreign products [12]. China's national identity is marked by the belief in the historical triumph of ancient Chinese civilization [15]. Today, maintaining national identity is a challenge in countries with diverse conditions, large immigrant populations, and multicultural countries [16]. Internal problems in the form of weakening national spirit and waning regional cultural values have also triggered racist conflicts, injustice, and national identity crises. The dissolution of the legacy of the past success stories between generations and the openness to change significantly shapes the youth, ignoring the urgency of national identity [17].

Each nation-state has its efforts to maintain a national identity. For example, Russia conducts promotions through state-controlled media [18]. Research [19] explores how Scottish Chinese children face challenges in establishing their identity. The results found that Scottish Chinese children (children born and lived in Scotland with Chinese parents) had judgments about their identity that changed with age. The strength of national identity was assessed in (Chinese) cultural identity, which was stronger at 8 years old than 14 years old.

For countries with diversity, the integration of multicultural values in learning has proven to strengthen national identity [20]. The Hong Kong Special 
Administrative Region (SAR) government introduces diverse cultural values into the school curriculum to maintain national identity through education [21]. In Indonesia, the implementation of multicultural values such as upholding justice, democracy, humanity, and pluralism has been done through strengthening education character regulation [22] in addition to the deconstruction idea of radicalization and racial conflict phenomenon through empowering moderate Islamic value [23]. Moderate Islam sign as the rise of religious conservatism in Indonesia since 1998 Reformation brings a new wave of Indonesian Islam, such as peaceful and inclusive [24]. Moderate Islamic values are expressed practically in several ways, including tolerance, harmony, and collaboration with various religious groups [25]. Individuals who have moderate Islamic values character and tolerance can avoid bullying and hate speech that is inappropriate [26].

Durkheim views bound interaction between religion and identity formation, especially as a reference for youth's national identity [27]. In line, religious dogma significantly influences Indonesian people's views and shapes individuals' ideology [28]. Then, religion values basically as the sign and expression of inherited youth national identity [29]. Commonly, the inherited national identity value is transmitted through the education system.

The education system has been commonly used to strengthen national identity. For example, Europe strengthens national identity through the propaganda of national history and sometimes myths that glorify past national events. In Australia, the education system develops a formal curriculum structure, which guides teachers to understand and maintain national identity [30]. Also, Israel resolves the conflicting narratives of Israeli and Palestinian citizens by developing a curriculum containing the national identity of students' countries of origin [31]. Then, the national identity in Japan is built through learning the Japanese language at school [32]. While the Chinese government has long made efforts to maintain national identity through traditional Chinese cultural education (TCC) [33].

Instilling ideological doctrines content through the school curriculum will become a platform for maintaining the values of national identity [34]. In Indonesia, the integration of local value into Education as early as possible is a means to strengthen national identity [35]. Teachers as main facilitators in learning play an important role in strengthening national identity by transferring knowledge of the history of a nation's struggle [36]. Then, the policy of strengthening character education has been carried out to maintain national identity [37]. Furthermore, the mission of moderate Islam that commonly consists of universal values can be integrated into education to maintain national identity [38].

Maintaining the harmony of social life during the globalization condition is important to instill moderate
Islamic value through the learning process. A study carried out by Jusmirah found that moderate Islamic value could decrease radicalism and build a respectful community [39]. This study focused on exploring the role of moderate Islamic values to strengthen national identity. This research is important as the alternative basis for the school to increase students' national identity based on moderate Islamic value in the learning process.

From those various explanations, the radicalism condition that exists in this last decade has been controlled by the government. And the suitable control system is instilling moderate Islamic value to the young generation through education. This study explores the implementation of moderate Islamic values in-school programs related to national identity.

\section{METHODS}

This research used a survey experiment in East Java Province conducted in September 2021. The data collection techniques through a survey by chatting or dialing the telephone. The questionnaire consists of 35 questions online through a google form. The questions were in the "1-5 Likert scale" format. The sample was 50 students from nine cities in East Java based on a stratified three-stage probability proportion to size random sample design to draw representative samples of secondary students to cover every district. The data was analyzed through statistical description with percentage techniques by describing the collected data without intending to draw conclusions or generalizations [40].

The focus of the research is to explore the implementation of moderate Islamic value in the school programs related to the national identity (implementation through intra-curricular, extracurricular, building school culture, and community participation). Moderate Islamic values consist of several indicators: tolerance in respecting diversity, inclusiveness to accept something new, logic and flexibility in thinking, problem solver, and social transformation [41]. Then, the national identity indicators related to 5 items: membership (contribution to the nation), private (a person's feelings as the nation member), public (another view of this country), identity (self-concept building), and comparison (related to compare with another country) [42].

\section{RESULTS AND DISCUSSION}

In this section, the researchers explore the school programs related to the national identity through intracurricular activities, extracurricular activities, building school culture, and various public participation activities.

The implementation of the moderate Islamic value to strengthen national identity through the intra-curricular activities that have been carried out has issued $84 \%$ (see Table 1). Several moderate Islamic values that could be implemented during intra-curricular are tolerance in diversity like being tolerant with other religions or racial. The intra-curricular practice consists of developing two 
main aspects; tolerance as permission and tolerance as mutual respect [41]. In a multicultural nation, tolerance is essential as one national identity aspect to strengthen membership.

The implication of this implementation makes the students tolerate each other. The diversity in Indonesia needs individuals to have a tolerant attitude to keep national unity. The unitarily will exist if the members of the nation tolerate other religions or races. This condition also makes the minority not blamed, but they feel respected as the same nation members.

Table 1. Recapitulation of the school program related to the national identity

\begin{tabular}{|l|l|c|c|c|c|}
\hline \multirow{2}{*}{ Related Aspect } & \multicolumn{4}{c|}{ Scale/Percentage } \\
\cline { 2 - 5 } & 1 & 2 & 3 & 4 & 5 \\
\hline $\begin{array}{l}\text { Implementation through } \\
\text { intracurricular activities }\end{array}$ & & & & 8 & 42 \\
$(16 \%)$ & $(84 \%)$ \\
\hline $\begin{array}{l}\text { Implementation through } \\
\text { extracurricular activities }\end{array}$ & & & & 5 & 45 \\
$(10 \%)$ & $(90 \%)$ \\
\hline $\begin{array}{l}\text { Implementation of activities } \\
\text { in building school culture }\end{array}$ & & 10 & $\begin{array}{c}15 \\
(20 \%)\end{array}$ & $\begin{array}{c}25 \\
(30 \%)\end{array}$ \\
\hline $\begin{array}{l}\text { Implementation in } \\
\text { community participation } \\
\text { activities }\end{array}$ & & & 5 & $\begin{array}{c}45 \\
(10 \%)\end{array}$ \\
$(90 \%)$
\end{tabular}

*Scale information: 1. Strongly Disagree, 2. Disagree,

3. Neutral, 4. Agree, 5. Strongly Agree.

The implementation of extracurricular activities carried out in building a national identity reached $90 \%$. Commonly, there are six merits of extracurricular activities in strengthening national identity through education: good citizenship perception, social accountability, intercultural awareness, democracy and human rights awareness, good skills of logical thinking, and interpersonal skills [42]. Several extracurricular activities above can strengthen the membership aspect. In the concept of national identity, membership is shown by the individual's contribution to the nation, such as becoming good citizens, caring for each other, and being open-minded.

The extracurricular activity that has to be implemented in the schools as the role in the 2013 Curriculum like Scout brings several shreds of evidence for students. From this extracurricular, they learn how to be good Indonesian citizens. They also learn to contribute to the nation. The guidance to receive the differentiation that exists makes students be open-minded people.

Next, implementing national identity values through activities to build school culture has several students' arguments: $50 \%$ strongly agree, $30 \%$ agree, and 20\% neutral. From those data, only a few students experienced a strengthened national identity through the school culture. In fact, the school culture changes individuals to better human life effectively [43]. The moderate value commonly implemented in the school is the student's habituation to be a good problem solver.

School culture as the whole school programs become the tools for shaping the student's character. The shared school vision and mission allow the students to be better humans. Different schools have different school cultures. But the schools always have the main purpose of making their students have good character related to national identity. The school culture can motivate the students to do better by giving suitable rules and regulations based on the school vision [44]. That condition could be the basis for the school to make the regulation based on moderate Islamic values to strengthen students' national identity. The regulation related to national identity indicators that can be formulated should allow inclusiveness to students' character to make students accept diversity.

Meanwhile, community participation has a significant role in strengthening national identity. In this case, students strongly agree (90\%) that this school program makes their national identity strengthened. Community participation needs the school system to be flexible and cooperative with the community and parental engagement based on experiential learning to strengthen national identity [45]. These community education programs support students' circumstances. This action has been implemented by the cooperative agreement between the school, parental engagement, and the environment around the school to make a system based on moderate Islamic values.

Community participation can be implemented by making relation with academic members, such as lectures, stakeholders, and users, as the guidance of school programs. Lecturers can advise arranging the school's program based on the scientific aspects. Stakeholders may give guidance to compose the school's activities, and the users can give notes about the competencies of students that the market needs. At last, parents as the leaders can control the students during their activities in their home.

\section{CONCLUSION}

From those findings, we can conclude that moderate Islamic values have been integrated into several school programs, such as intra-curricular, extracurricular, building school culture, and community participation. The value of tolerance in diversity, like obeying another religion or racial has been implemented during intracurricular activities. Then, the membership as the Indonesian citizens is shown by the individual's attitude such as care each other, being open-minded, and trying to be good citizenship that learned from extracurricular activities. Generally, only a few students feel their school culture has implemented moderate value to strengthen national identity through the habituation to be a good problem solver. Last, community participation has been built through the cooperative action between the school, 
parental engagement, and the environment around the school to make a pattern based on moderate Islamic values. Then the theoretically, the implication of this study found that moderate Islamic value can decrease radicalism thought. And practically, this study can serve as the suggestion for the standard school system to maintain students' national identity.

\section{AUTHORS' CONTRIBUTIONS}

All authors conceived and designed this study. All authors contributed to the process of revising the manuscript, and in the end, all authors have approved the final version of this manuscript.

\section{REFERENCES}

[1] A. Murphy, Charting the Emergence of National Identity in Children in Wales, Child. Soc., vol. 32, no. 4, 2018, pp. 301-313. doi: 10.1111/chso.12252.

[2] J. Walton, N. Priest, E. Kowal, F. White, B. Fox, and Y. Paradies, Whiteness and national identity: teacher discourses in Australian primary schools, Race Ethn. Educ., vol. 21, no. 1, 2018, pp. 132-147. doi: 10.1080/13613324.2016.1195357.

[3] S.E. Ha, S.J. Jang, Immigration, threat perception, and national identity: Evidence from South Korea, Int. J. Intercult. Relations, vol. 44, 2015, pp. 53-62. doi: 10.1016/ j.ijintrel.2014.12.001.

[4] M. Saeedeh, S. Abbas, The Relationship between National Identity and Religious Identity in the Zoroastrian Community, vol. 22, no. 185. NATIONAL STUDIES, Jan. 01, 2021, pp. 91-110. Accessed: Sep. 30, 2021. [Online]. Available: https://www.sid.ir/en/Journal/ViewPaper.aspx?ID= 799372.

[5] L. Boser, I. Brühwiler, Languages, script and national identity: Struggles over linguistic heterogeneity in Switzerland in the nineteenth and twentieth centuries," Hist. Educ., vol. 46, no. 3, pp. 306-323, 2017, doi: 10.1080/ 0046760X.2016.1267267.

[6] J. Packer, R. Ballantyne, D. Uzzell, Interpreting war heritage: Impacts of Anzac museum and battlefield visits on Australians' understanding of national identity, Ann. Tour. Res., vol. 76, May 2019, pp. 105-116. doi: 10.1016/J.ANNALS.2019.03.012.

[7] T. Lucas, E. Barkho, C. Rudolph, L. Zhdanova, M. Fakhouri, L. Thompson, Political affiliation, collective self-esteem and perceived employability of immigrants: Inducing national identity polarizes host-nation employers, Int. J. Intercult. Relations, vol. 39, no. 1, 2014, pp. 136-151. doi: 10.1016/j.ijintrel.2013.11.001.
[8] Q. Liu and D. Turner, Identity and national identity, Educational Philosophy and Theory, vol. 50 (12), Feb 2018, pp. 1080-1088. doi: 10.1080/ 00131857.2018 .1434076 .

[9] S.Y. Choi, M. Abel, A. Siqi-Liu, S. Umanath, National Identity Can be Comprised of More Than Pride: Evidence From Collective Memories of Americans and Germans, J. Appl. Res. Mem. Cogn., vol. 10(1), Mar. 2021, pp. 117-130. doi: 10.1016/J.JARMAC.2020.09.004.

[10] E. Sinkkonen, Nationalism, patriotism and foreign policy attitudes among Chinese university students, China Q., no. 216, 2013, pp. 1045-1063. doi: 10.1017/S0305741013001094.

[11] O. David, D. Bar-Tal, A Sociopsychological Conception of Collective Identity: The Case of National Identity as an Example, Personality and Social Psychology Review 13(4), Sept. 2009, pp. 354-379. doi: 10.1177/1088868309344412.

[12] S.W. Carvalho, D. Luna, E. Goldsmith, The role of national identity in consumption: An integrative framework, J. Bus. Res., vol. 103, Oct. 2019, pp. 310-318. doi: 10.1016/J.JBUSRES.2019.01.056.

[13] A. Georgiadis A. Manning, One nation under a groove? Understanding national identity, J. Econ. Behav. Organ., vol. 93, 2013, pp. 166-185. doi: 10.1016/j.jebo.2012.10.013.

[14] R. Bond, Multicultural nationalism? National identities among minority groups in Scotland's census, J. Ethn. Migr. Stud., vol. 43(7), 2017, pp. 1121-1140. doi: 10.1080/1369183X.2016.1232162.

[15] H. Huang, X. Liu, Historical knowledge and national identity: Evidence from China, Research and Politics, vol. 5(3):205316801879535, July. $2018 . \quad$ doi: https://doi.org/10.1177/ 2053168018794352 ,

[16] I. McAllister, National identity and attitudes towards immigration in Australia*, National Identities, vol. 20, no. 2, Sept. 2016, pp. 157-173. doi: 10.1080/14608944.2016.1206069.

[17] K. Vlachová, Significant others and the importance of ancestry for Czech national identity, National Identities, vol. 21, no. 1, August. 2017, pp. 57-72. doi: 10.1080/14608944.2017.1362378.

[18] P. Goble, Russian national identity and the Ukrainian crisis, Communist Post-Communist Stud., vol. 49, no. 1, 2016, pp. 37-43. doi: 10.1016/j.postcomstud.2015.12.006.

[19] Q. Dai, J. Williams, E. McGregor, Am I 'Chinese' or 'Scottish'? children's perceptions of the adaptive 
nature of Chinese Scottish children's dual identities, Eur. J. Dev. Psychol., vol. 15, no. 2, 2018, pp. 224242. doi: 10.1080/17405629.2017.1300578.

[20] R.N. Setyowati, Sarmini, Analysis of Learning Model of Civic Education Based on Multicultural Education to Build Indonesian Identity for Young Generation in Surabaya, Adv. Soc. Sci. Educ. Humanit. Res., vol. 226, no. Icss, 2018, pp. 15671571.

[21] W.-C. Ho, W.-W. Law, The struggle between globalization, nationalism and music education in Hong Kong, Music Education Research, vol. 11(4), 2004, pp. 1-18,

[22] U. Masamah, M. Huda, Multicultural Education and the Nationalistic Reality (Photograph the Role of Teachers in Building a Multicultural Awareness in Indonesia), QIJIS (Qudus Int. J. Islam. Stud., vol. 4, no. 1, 2016, pp. 68-81. doi: 10.21043/ QIJIS.V4I1.1578.

[23] S. Susilo, R.P. Dalimunthe, Moderate southeast Asian Islamic education as a parent culture in deradicalization: Urgencies, strategies, and challenges, Religions, vol. 10, no. 1, 2019, pp. 45. doi: 10.3390/rel10010045.

[24] A.A. Safei, Promoting moderate Islam in a global community through the 'English for Ulama' programme, HTS Teologiese Studies 77(2), 2018, pp. 1-8.

[25] M. Hilmy, Whither Indonesia's Islamic moderatism?: A reexamination on the moderate vision of Muhammadiyah and NU, J. Indones. Islam, vol. 7, no. 1, 2013, pp. 24-48. doi: 10.15642/JIIS.2013.7.1.24-48.

[26] A. Shunhaji, F. Lestari, Implementation of Moderate Islamic Curriculum in the Establishment of Student Character, J. Educ. Pract., vol. 11, no. 36, 2020, pp. 30-40. doi: 10.7176/jep/11-36-04.

[27] S.H. Oppong, Religion and Identity, Am. Int. J. Contemp. Res., vol. 3, no. 6, 2013, pp. 113-123.

[28] M. Zuhdi, Challenging moderate Muslims: Indonesia's Muslim schools in the midst of religious conservatism, Religions, vol. 9, no. 10, 2018, p. 310. doi: $10.3390 /$ rel9100310.

[29] S. Sikka, Pluralism About What? Religion as Belief and Identity, in: Re-thinking Relig. Plur., 2021, pp. 3-19. doi: 10.1007/978-981-15-9540-0_1.

[30] C.C. Walton, R.J. Keegan, M. Martin, H. Hallock, The potential role for cognitive training in sport: More research needed, Front. Psychol., vol. 9, no. JUL, 2018, pp. 1-7. doi: 10.3389/ fpsyg.2018.01121.

[31] K. Arar, F. Ibrahim, Education for national identity: Arab schools principals and teachers dilemmas and coping strategies, Journal of Education Policy, vol. 31, no. 6, 2016, pp. 681-693. doi: 10.1080/02680939.2016.1182647.

[32] B. Turnbull, Learner perspectives on national identity and EFL education in Japan: Report of a questionnaire study. Journal of Asia TEFL, Vol 14(2), 2017, pp. 211-227.doi: 10.18823/ asiatefl.2017.14.2.1.211.

[33] S. Xu, Cultivating national identity with traditional culture: China's experiences and paradoxes, Discourse, vol. 6306, no. April 2017, pp. 1-14. doi: 10.1080/01596306.2017.1302410.

[34] S. Dobrocká, E. Szórádová, School curriculum as a means of shaping national identity : music education in the Slovak region of Czechoslovakia in the interwar period ( 1918 - 1939 ), Pedagog. Cult. Soc., vol. 1366, 2017, pp. 1-15. doi: 10.1080/ 14681366.2017.1365751.

[35] F. Rizkiyani, Strengthening national identity through civic education for young children: A case study of Indonesia, Int. J. Eng. Technol., vol. 7, no. 3, 2018, pp. 291-294. doi: 10.14419/ ijet.v7i3.25.17584.

[36] Sarmini, R.N. Setyowati, A.D.B. El Rizaq, Understanding of Multiculturalism Material: The CivicTeachers Way in Enhancing Nationalism Based on Multiculturalism Education for Young Generation in Surabaya, Advances in Social Science, Education and Humanities Research, volume 473, 2020, pp. 260-264. doi: 10.2991/assehr.k.201014.056.

[37] R. Arief, L.Y. Prakoso, H. Risman, Understanding National Identity To Create Love And Proud Of Being A Part Of The Indonesian Nation, J. Inov. Penelit., vol. 1, no. 11, Apr. 2021, pp. 2549-2556. doi: 10.47492/JIP.V1I11.518.

[38] Habibi, T.S. Pitana, Susanto, Protecting National Identity Based On The Value Of Nation Local Wisdom, Int. J. Malay-Nusantara Stud., vol. 1, no. 2, 2018, pp. 24-40. [Online]. Available: http://journal.unhas.ac.id/index.php/IJoMNS/article/view/5516.

[39] R. Kamal, Internalization of Moderate Islamic Values in Education, Islam. Stud. J. Soc. Transform., vol. 1, no. 1, 2017, pp. 67-80.

[40] W.L. Diehl, M. Arbeitspapiere, Measuring National Identity, Encycl. Qual. Life Well-Being Res., no. 10, 1999, pp. 3941-3953. doi: 10.1007/978-94-007-0753-5_4143. 
[41] E. Langmann, Tolerance and Education, In Oxford Research Encyclopedia of Education. Oxford University Press. 2021. doi: https://doi.org/10.1093/ acrefore/9780190264093.013.1512.

[42] F.K. Aschenberger, H. Akar, A. Yildirim, The role of extracurricular activities in active citizenship education, Curriculum Studies, vol. 43, no. 6, Dec. 2011, pp. 809-837.doi: 10.1080/ 00220272.2011 .591433 .

[43] L. Ravindran, The Effects of School Culture Impacting on the Process of Change, Redesigning Learn. Gt. Soc. Impact, 2018, pp. 141-147. doi: 10.1007/978-981-10-4223-2_12.

[44] J. Tus, An Assessment of the School Culture and Its Impact, Int. J. All Res. Writings, vol. 1, no. 11, 2020, pp. 23-28.

[45] R. Iyengar, Rethinking community participation in education post Covid-19, Prospect 51(1). 2021, pp. 1-11. doi: 10.1007/S11125-020-09538-2. 